\title{
(2) snomen \\ (๐) OPEN ACCESS \\ Genital HSV-1 DNA detection is associated with a low inflammatory profile in HIV-uninfected South African women
}

\author{
Andile Mtshali, ${ }^{1,2}$ Sinaye Ngcapu, ${ }^{1,2}$ Farzana Osman, ${ }^{1}$ Nigel Garrett, ${ }^{1,3}$ \\ Ravesh Singh (1) , ${ }^{2,4}$ Anne Rompalo, Adrian Mindel, ${ }^{1,6}$ Lenine J P Liebenberg (1) 1,2
}

${ }^{1}$ Centre for the AIDS Programme of Research in South Africa, Durban, KwaZulu-Natal, South Africa

${ }^{2}$ School of Laboratory Medicine and Medical Sciences, University of KwaZulu-Natal, Durban, KwaZulu-Natal, South Africa ${ }^{3}$ Discipline of Public Health, University of KwaZulu-Natal, Durban, KwaZulu-Natal, South Africa

${ }^{4}$ Department of Microbiology, National Health Laboratory Services, KwaZulu-Natal Academic Complex, Inkosi Albert Luthuli Central Hospital, Durban, South Africa ${ }^{5}$ Johns Hopkins School of Medicine, Baltimore, Maryland, USA

${ }^{6}$ Sydney Medical School, The University of Sydney, Sydney, New South Wales, Australia

\section{Correspondence to} Dr Lenine I P Liebenberg, Centre for the Aids Programme of Research in South Africa, Durban 4013, South Africa; lenine.liebenberg@caprisa.org

Received 24 January 2020 Revised 18 July 2020

Accepted 26 July 2020 Published Online First 26 August 2020

\section{Check for updates}

(c) Author(s) (or their employer(s)) 2021. Re-use permitted under CC BY-NC. No commercial re-use. See rights and permissions. Published by BMJ.

To cite: Mtshali $A$, Ngcapu S, Osman F, et al. Sex Transm Infect 2021:97:33-37.

\section{ABSTRACT}

Objectives Genital herpes simplex virus (HSV) infections are common in South Africa and worldwide. While HSV-2 is known to cause genital lesions, HSV-1 is better known to cause oral infections. Due to the global rise in genital HSV-1 infections, we aimed to compare the genital cytokine environment associated with HSV-1 and HSV-2 infections and their relation to the proinflammatory genital immune environment associated with HIV risk in African women.

Methods HSV-1 and HSV-2 DNA were detected by quantitative real-time PCR in menstrual cup specimens collected from 251 HIV-negative women participating in the CAPRISA 083 study in Durban, South Africa. HSV shedding was defined as detection at $>150$ copies $/ \mathrm{mL}$. Forty-eight cytokines were measured in genital fluid by multiplexed ELISA, and multivariable regression models determined associations between genital cytokines and HSV DNA detection.

Results HSV-1 DNA detection (24/251 (9.6\%)) and shedding (13/24 (54.2\%)) was more common than HSV-2 (detection in 14/251 (5.6\%), shedding in 0/14). None of the women with detectable HSV had evidence of genital lesions. HSV-2 DNA detection was associated with increased interleukin (IL)-18 and decreased cutaneous T-cell attracting chemokine concentrations, but only in univariable analysis. By contrast, in both univariable and multivariable analyses, the detection of HSV-1 DNA was associated with reduced concentrations of granulocyte-colony stimulating factor, IL-7, IL-4, platelet-derived growth factor- $\beta \beta$ and five proinflammatory cytokines associated with HIV risk: IL-6, IL-1 $\beta$, macrophage inflammatory protein (MIP) $-1 \alpha$, MIP$1 \beta$ and tumour necrosis factor- $\alpha$.

Conclusions That HSV-1 DNA was more commonly detected and shed than HSV-2 emphasises the need for clinical screening of both viruses, not just HSV-2 in young women. Efforts to reduce genital inflammation may need to consider implementing additional strategies to mitigate a rise in HSV replication.

\section{INTRODUCTION}

Genital herpes is an STI commonly associated with ulcerative lesions in the genital area of men and women. It is caused by herpes simplex viruses (HSV), which are subdivided into types 1 and 2 . Genital herpes is predominantly attributed to HSV-2 infection, while HSV-1 primarily infects the oral cavity, but can also affect the genital tract. ${ }^{1}$ Several studies have reported an increasing prevalence of genital HSV-1 infection. ${ }^{23}$

Genital inflammation is associated with increased risk of HIV infection in young women. ${ }^{45}$ Active HSV-2 infection in the genital tract is associated with viral shedding and/or inflammation, ${ }^{6}$ and also results in the recruitment of $\mathrm{CD}^{+}{ }^{+}$T-cell HIV targets. ${ }^{7-9}$ Although the link between genital HSV-1 and HIV is not well understood, HSV-1 may have a similar influence on HIV transmission due to its relatedness to HSV-2 viral properties and its manner of disease causation. ${ }^{10}$ Lymphocyte recruitment and the release of cytokines such as type 1 interferons, interleukin (IL)-1 $\beta$ and other pro-inflammatory cytokines play a role in mounting efficient immune responses against HSV infections, ${ }^{11} 12$ and suboptimal immunity may likely lead to uncontrolled viral replication and increased detection of HSV DNA. ${ }^{13}$ Although HSV-specific immune responses have been widely studied in non-human models, multiple lines of conflicting evidence exist, and these need to be fully characterised in human models to better understand the course of infection. ${ }^{14}$

Given the existing evidence that inflammatory cytokines in the genital tract compromise epithelial barrier integrity and facilitate HIV target cell recruitment, ${ }^{15}$ we assessed different cytokines associated with cellular recruitment, immune regulation, innate and adaptive responses, and particularly the proinflammatory cytokines previously linked to HIV risk in our population. ${ }^{4}$ We correlated these to HSV status to test the hypothesis that genital HSV infections contribute to the genital cytokine environment associated with the increased risk of HIV infection in young women. Understanding the causes of genital inflammation may contribute to the design of effective mitigation measures that reduce the risk of HIV infection.

\section{METHODS}

\section{Participants and specimen collection}

This study presents a cross-sectional analysis of data collected from the CAPRISA 083 study evaluating the impact of point-of-care (POC) Chlamydia trachomatis (CT), Neisseria gonorrhoea (NG) and Trichomonas vaginalis (TV) testing, immediate treatment and expedited partner therapy on genital inflammation. ${ }^{16}$ The study included a cohort of 
young, non-pregnant, HIV-uninfected women attending the Prince Cyril Zulu Communicable Diseases Centre for sexual and reproductive services in Durban, South Africa. ${ }^{17}$ Women were excluded from the study if they reported the use of antibiotics or HSV treatments within the past 7 days or had engaged in any form of sex work. A total of 251 enrolled women consenting to genital specimen collection were included in this secondary analysis of baseline data. The prevalence of CT, NG, TV and bacterial vaginosis (BV) in the cohort has been previously reported. ${ }^{17}$ The genital swab specimens for STI and BV screening were collected using sterile Dacron swabs, and menstrual cups (MCs) (SoftCup; Instead, San Diego, CA) for HSV screening and cytokine assessment. ${ }^{17}$ MCs were inserted vaginally by a study nurse, removed after approximately 2 hours and placed into $50 \mathrm{~mL}$ conical tubes for processing. ${ }^{18} \mathrm{MC}$ pellets were used for DNA extraction while supernatants were used for assessments of cytokine concentrations.

\section{Laboratory detection of HSV DNA}

In-house quantitative real-time PCR was conducted for screening of HSV-1 and HSV-2 using the Applied Biosystems QuantStudio 5 Real-Time PCR system (ThermoFisher Scientific, Waltham, MA). Briefly, DNA was extracted from MC pellets using the Roche MagNA Pure instrument (Roche Diagnostics, Indianapolis, IN, USA) kit as per manufacturer's instructions. The master mix for HSV-2 (assay ID: Vi04646232_s1) was prepared by adding $2.5 \mu \mathrm{L}$ PCR-grade water (Qiagen, Germany), $0.25 \mu \mathrm{L}$ FAM-labelled probe/primer mix, $1.25 \mu \mathrm{L}$ Fast Start $4 \times$ probe master mix (ThermoFisher, Part No. 4444434) and $1 \mu \mathrm{L}$ DNA to make the total volume of $5 \mu \mathrm{L}$ per sample. Amplification was performed at $95^{\circ} \mathrm{C}$ for $30 \mathrm{~s}$ followed by 45 cycles comprising denaturation at $95^{\circ} \mathrm{C}$ for $3 \mathrm{~s}$ and annealing at $60^{\circ} \mathrm{C}$ for $30 \mathrm{~s}$. Detection of amplified fluorescent products was carried out at the end of the annealing phase. The same volumes were used for the detection of HSV-1 except for the substitution of the commercial probe with the validated customised version adopted from Namvar et al. ${ }^{19}$ Standard curves of known copy numbers were made from ultra-purified HSV-1 and HSV-2 isolated from the positive patients. Data were collected using the Applied Biosystems QuantStudio 5 V.2.3 software (ThermoFisher Scientific, Waltham, MA). Known HSV-positive and HSV-negative samples from clinical isolates were included as internal controls. Samples with 5 copies $/ \mu$ L of HSV DNA and cycle threshold of $<32$ were considered positive for HSV, and shedding was defined as HSV DNA detected at $>150$ copies $/ \mathrm{mL}^{20-23}$

\section{Cytokine detection and analysis}

The concentrations of 48 cytokines were measured from stored MC supernatants using the Bio-Plex Pro Human Cytokine Group I and II multiplexed ELISA Panels (Bio-Rad Laboratories, Hercules, CA, USA) as previously described. ${ }^{18}$ Cytokine data were collected using the Bio-Plex 200 system V.6.0 software (Bio-Rad Laboratories). The sensitivity of these kits ranged between 0.2 and $45.2 \mathrm{pg} / \mathrm{mL}$ for each cytokine measured. Values that were above the limit of detection were assigned double the maximum value of the analyte, while those below the detectable limit were assigned half the minimum detected value. ${ }^{18}$ Cytokine assessments were repeated if correlation coefficients between replicates were below Spearman rho $=0.8$ and if significant differences in concentration magnitudes were observed among replicates.

\section{STATISTICAL ANALYSIS}

Descriptive statistics were used to summarise baseline characteristics and were expressed as medians with IQRs for continuous variables and proportions for categorical variables. WilcoxonMann-Whitney test was used to compare two medians and the Fisher exact test was used to compare proportions. Univariable and multivariable linear regression models were used to identify independent associations with HSV-1 infection. P values less than 0.05 were considered significant. The false discovery rate method was used to correct for multiple comparisons for cytokine comparisons. Statistical analysis was performed using SAS V.9.4 (SAS Institute, Cary, NC, USA).

\section{RESULTS \\ HSV DNA prevalence and associations with participant characteristics}

A total of 251 women, with a median age of 23 years (IQR 21-27), were included in this study. Genital HSV-2 DNA was detected in 5.6\% (14/251) participants, none of whom were shedding virus (all $<150$ copies $/ \mathrm{mL}$ ). In contrast, HSV-1 DNA was detected in $9.6 \%(24 / 251)$ participants, and 13/24 (54.2\%) were shedding HSV-1 at the genital tract. There were no cases of HSV-1 and HSV-2 co-infection. While 51/251 (20.3\%) of the study population had other STIs (CT, TV and/or NG), none were detected among the 24 women with HSV-1 DNA and only 2/14 (14.3\%) women with detectable HSV-2 DNA were co-infected with other STIs (one with NG and the other with both CT and TV). The detection of HSV DNA was not associated with any of the demographic, behavioural and reproductive health factors measured in the CAPRISA 083 study (online supplementary table 1).

\section{Associations between cytokine concentrations and HSV DNA detection}

We compared genital cytokine concentrations among women with and without detectable HSV DNA. In multivariable analyses controlling for BV status, the number of sexual partners in the last 2 months and the outcome of the genital examination, the detection of HSV-1 DNA was significantly associated with lower concentrations of granulocyte-colony stimulating factor (G-CSF; $\beta=-0.55, p=0.021), \quad$ IL-6 $(\beta=-0.36, p=0.033)$, IL-7 $(\beta=-0.51, p=0.017), I L-1 \beta(\beta=-0.70, p=0.008)$, IL-4 $(\beta=-0.84, \quad p \leq 0.001)$, macrophage inflammatory protein (MIP) $-1 \alpha(\beta=-0.97, p \leq 0.001)$, MIP-1 $\beta(\beta=-0.68, p=0.013)$, platelet-derived growth factor (PDGF) $-\beta \beta(\beta=-0.81, p=0.005)$ and tumour necrosis factor (TNF)- $\alpha \quad(\beta=-0.38, \mathrm{p}=0.013)$ concentrations compared with women with no detectable genital HSV-1 DNA (table 1). Observations of reduced concentrations of IL-4 and MIP- $1 \alpha$ remained significant after controlling for multiple comparisons. In contrast, HSV-2 DNA detection was associated with increased IL-18 $(\beta=0.59, p=0.045)$ and decreased cutaneous T-cell attracting chemokine (CTACK; $\beta=-0.01, p=0.009$ ) concentrations, but only in univariable analysis (online supplementary table 2). Multivariable analysis was not performed for HSV-2, considering the sample size and minimal differences observed in univariable analysis.

\section{DISCUSSION}

Definitive diagnosis and management of HSV infections remain challenging due to asymptomatic infections that often go unnoticed. Despite the global trend in rising genital HSV-1 prevalence, ${ }^{24}$ many healthcare facilities in low-income and middle-income countries employ strategies detecting exposure or current infection of HSV-2 alone, or the HSV types indiscriminately. Here, we used a sensitive real-time quantitative PCR specific for the detection of genital HSV-1 and HSV-2 
Table 1 Baseline associations between cytokine concentrations and HSV-1 DNA detection

\begin{tabular}{|c|c|c|c|c|}
\hline Cytokine & $\begin{array}{l}\text { Univariable } \\
\beta(95 \% \mathrm{Cl})\end{array}$ & $P$ value & $\begin{array}{l}\text { Multivariable } \\
\boldsymbol{\beta}(95 \% \mathrm{Cl})\end{array}$ & $P$ value \\
\hline IL-1 $\alpha$ & $-0.03(-0.44$ to 0.38$)$ & 0.885 & $-0.01(-0.41$ to 0.38$)$ & 0.954 \\
\hline IL-1 $\beta$ & $-0.70(-1.22$ to -0.18$)$ & 0.008 & $-0.66(-1.16$ to -0.16$)$ & 0.009 \\
\hline IL-6 & $-0.36(-0.69$ to -0.03$)$ & 0.033 & $-0.34(-0.67$ to -0.01$)$ & 0.040 \\
\hline IL-12p40 & -0.18 ( -0.86 to 0.51$)$ & 0.615 & $-0.21(-0.89$ to 0.48$)$ & 0.548 \\
\hline IL-12p70 & $-0.13(-0.65$ to 0.39$)$ & 0.615 & $-0.14(-0.66$ to 0.38$)$ & 0.595 \\
\hline IL-18 & $-0.05(-0.51$ to 0.41$)$ & 0.835 & $-0.01(-0.45$ to 0.44$)$ & 0.973 \\
\hline MIF & $0.02(-0.41$ to 0.45$)$ & 0.935 & $0.07(-0.35$ to 0.48$)$ & 0.752 \\
\hline TNF- $\alpha$ & $-0.38(-0.69$ to -0.08$)$ & 0.013 & $-0.37(-0.66$ to -0.07$)$ & 0.016 \\
\hline TNF- $\beta$ & $0.18(0.30$ to 0.65$)$ & 0.463 & $0.18(-0.29$ to 0.64$)$ & 0.462 \\
\hline TRAIL & $-0.20(-0.89$ to 0.49$)$ & 0.562 & $-0.16(-0.82$ to 0.50$)$ & 0.628 \\
\hline CTACK & $0.29(-0.31$ to 0.89$)$ & 0.343 & $0.25(-0.34$ to 0.84$)$ & 0.407 \\
\hline EOTAXIN & $-0.65(-1.31$ to 0.01$)$ & 0.054 & $-0.63(-1.29$ to 0.03$)$ & 0.060 \\
\hline GRO- $\alpha$ & $0.01(-0.61$ to 0.62$)$ & 0.985 & $0.01(-0.59$ to 0.61$)$ & 0.973 \\
\hline IL-8 & $-0.19(-0.64$ to 0.27$)$ & 0.415 & $-0.16(-0.61$ to 0.28$)$ & 0.474 \\
\hline IL-16 & $-0.20(-0.86$ to 0.47$)$ & 0.559 & $-0.19(-0.85$ to 0.48$)$ & 0.582 \\
\hline IP-10 & $-0.29(-0.92$ to 0.33$)$ & 0.358 & $-0.31(-0.91$ to 0.29$)$ & 0.319 \\
\hline MCP-1 & $-0.01(-0.46$ to 0.44$)$ & 0.961 & $-0.041(-0.49$ to 0.41$)$ & 0.858 \\
\hline MCP-3 & $-0.03(-0.78$ to 0.71$)$ & 0.929 & $-0.02(-0.77$ to 0.72$)$ & 0.953 \\
\hline MIG & $-0.20(-0.61$ to 0.21$)$ & 0.332 & $-0.20(-0.61$ to 0.21$)$ & 0.337 \\
\hline MIP-1 $\alpha^{*}$ & $-0.97(-1.49$ to -0.44$)$ & $<0.001$ & $-0.92(-1.43$ to -0.42$)$ & $<0.001$ \\
\hline MIP-1 $\beta$ & $-0.68(-1.22$ to -0.14$)$ & 0.013 & $-0.64(-1.17$ to -0.11$)$ & 0.018 \\
\hline RANTES & $-0.56(-1.21$ to 0.09$)$ & 0.090 & $-0.55(-1.19$ to 0.09$)$ & 0.093 \\
\hline IFN- $\alpha 2$ & $0.28(-0.32$ to 0.88$)$ & 0.352 & $0.29(-0.31$ to 0.89$)$ & 0.336 \\
\hline SDF-1 $\alpha$ & $0.05(-0.21$ to 0.30$)$ & 0.717 & $0.04(-0.21$ to 0.29$)$ & 0.749 \\
\hline$\beta$-NGF & $0.29(-0.40$ to 0.97$)$ & 0.416 & $0.29(-0.40$ to 0.98$)$ & 0.416 \\
\hline FGF BASIC & $-0.26(-0.83$ to 0.32$)$ & 0.380 & $-0.29(-0.86$ to 0.28$)$ & 0.315 \\
\hline G-CSF & $-0.55(-1.01$ to -0.08$)$ & 0.021 & $-0.54(-1.01$ to -0.08$)$ & 0.022 \\
\hline GM-CSF & $0.07(-0.41$ to 0.54$)$ & 0.784 & $0.02(-0.45$ to 0.48$)$ & 0.937 \\
\hline HGF & $-0.21(-0.69$ to 0.27$)$ & 0.389 & $-0.18(-0.66$ to 0.29$)$ & 0.448 \\
\hline IL-3 & $0.04(-0.53$ to 0.62$)$ & 0.883 & $0.05(-0.52$ to 0.62$)$ & 0.868 \\
\hline IL-7 & $-0.51(-0.92$ to -0.09$)$ & 0.017 & $-0.49(-0.9$ to -0.08$)$ & 0.020 \\
\hline IL-9 & -0.26 (-0.64 to 0.12$)$ & 0.178 & $-0.25(-0.62$ to 0.12$)$ & 0.181 \\
\hline LIF & $-0.09(-0.49$ to 0.31$)$ & 0.662 & $-0.07(-0.45$ to 0.32$)$ & 0.736 \\
\hline M-CSF & $-0.13(-0.48$ to 0.22$)$ & 0.456 & $-0.12(-0.47$ to 0.23$)$ & 0.497 \\
\hline PDGF- $\beta \beta$ & $-0.81(-1.37$ to -0.24$)$ & 0.005 & $-0.79(-1.35$ to -0.23$)$ & 0.006 \\
\hline SCF & $-0.42(-1.24$ to 0.39$)$ & 0.307 & $-0.42(-1.23$ to 0.39$)$ & 0.306 \\
\hline SCGF- $\beta$ & $-0.20(-0.53$ to 0.14$)$ & 0.245 & $-0.18(-0.51$ to 0.15$)$ & 0.287 \\
\hline VEGF & $-0.27(-0.73$ to 0.19$)$ & 0.255 & $-0.27(-0.72$ to 0.19$)$ & 0.253 \\
\hline IFN- $\gamma$ & $-0.13(-0.62$ to 0.36$)$ & 0.605 & $-0.09(-0.58$ to 0.39$)$ & 0.705 \\
\hline IL-2 & $-0.18(-0.83$ to 0.48$)$ & 0.598 & $-0.19(-0.84$ to 0.46$)$ & 0.566 \\
\hline IL-4* & $-0.84(-1.30$ to -0.37$)$ & $<0.001$ & $-0.82(-1.27$ to -0.37$)$ & $<0.001$ \\
\hline IL-5 & $-0.12(-0.70$ to 0.46$)$ & 0.691 & -0.08 ( -0.65 to 0.49$)$ & 0.781 \\
\hline IL-13 & $0.61(-0.10$ to 1.32$)$ & 0.094 & $0.62(-0.08$ to 1.32$)$ & 0.085 \\
\hline IL-15 & $0.15(-0.41$ to 0.70$)$ & 0.596 & $0.13(-0.41$ to 0.67$)$ & 0.642 \\
\hline IL-17A & $-0.11(-0.87$ to 0.65$)$ & 0.768 & $-0.09(-0.85$ to 0.66$)$ & 0.807 \\
\hline IL-2R $\alpha$ & $-0.19(-0.74$ to 0.36$)$ & 0.496 & $-0.18(-0.73$ to 0.36$)$ & 0.509 \\
\hline IL-10 & $-0.17(-0.61$ to 0.28$)$ & 0.456 & $-0.17(-0.61$ to 0.27$)$ & 0.452 \\
\hline IL-1RA & $-0.06(-0.66$ to 0.53$)$ & 0.831 & $-0.07(-0.66$ to 0.53$)$ & 0.824 \\
\hline
\end{tabular}

${ }^{\beta}$ Coefficients and corresponding $p$ values were determined using linear regression.

Multivariable regression models were adjusted for Nugent's score, number of sexual partners in the last 2 months and genital examination. Significant $\mathrm{p}$ values $(<0.05)$ are indicated in bold and significance after false discovery rate adjustment is indicated by (*). Abbreviations: interleukin (IL)-1 B, IL-1RA, IL-2, IL-4, IL-5, IL-6, IL-7, IL-8, IL-9, L10, I-12p70, IL-12p40, L-16, L-18, L-1 $\alpha,\|-2 R \alpha\|-3,,\|-13\|-15,, \|-17$, basic fibroblast growth factor (FGF), cutaneous T-cell attraction cutaneous T-cell attraction chemokine (CTACK), eotaxin, granulocyte colony stimulating factor (G-CSF), granulocyer macrophage colony stimulating factor (GM-CSF), growth regulated (GRO)- $\alpha$, hepatocyte growth factor (HGF), interferon (IFN)- $\gamma$, IFN- $\alpha 2$, interferon gamma induced protein (IP) - 10, leukaemia inhibitory factor (LFF), monoc chemotactic protein (MCP) -1, MCP-3, macrophage colony-stimulating factor (M-CSF), monokine induced by (MIP)- 1 a (MIP) $-1 \alpha, M P-1 \beta$, nerve growth factor (NGF)- $\beta$, platelet-derived growth factor (PDGF)- $\beta \beta$, regulated on activation ell growth factor (SCGF)- $\beta$, (TNF)- $\alpha$, TNF- $\beta$.

CTACK, cutaneous T-cell attraction chemokine; FGF, fibroblast growth factor; G-CSF, granulocyte colony stimulating factor; GM-CSF, granulocyte macrophage colony stimulating factor ; GRO-a, growth regulated-alpha; HGF, hepatocyte growth factor; IFN, interferon; IL, interleukin; IP-10, interferon gamma induced protein; LIF, leukaemia inhibitory factor ; MCP, monocyte chemotactic protein; M-CSF, macrophage colony-stimulating factor; MIF, macrophage migration inhibitory factor ; MIG, monokine induced by gamma-interferon; MIP, macrophage inflammatory protein; NGF, nerve growth factor; PDGF, platelet-derived growth factor; RANTES, regulated on activation normal T cell expressed and presumably secreted; SCF, stem cell factor; SCGF, stem cell growth factor; SDF, stromal-derived factor; TNF, tumour necrosis factor; TRAIL, TNF-related apoptosis inducing ligand; VEGF, vascular endothelial growth factor.
DNA and evaluated the contribution of HSV positivity to the genital cytokine environment. We observed a high proportion of women with detectable genital HSV-1 DNA, in line with several international reports of increasing genital HSV-1 detection. ${ }^{25-27}$ However, contrary to evidence of lower frequencies of genital HSV-1 transmission and reactivation than that for genital HSV $-2,{ }^{28}$ we observed a greater degree of genital HSV-1 than HSV-2 replication in this population of young women at high risk of HIV infection. The reasons for this are still unclear, but may be related to seeding from increased frequencies of oralgenital contact in this population. ${ }^{29}{ }^{30}$ Nonetheless, our observation of replicating HSV-1 and HSV-2 in the genital tract of young women emphasises the need for clinical screening for both viruses.

Compared with women with no detectable genital HSV-1 DNA, the presence of HSV-1 DNA was associated with significant decreases in genital concentrations of G-CSF, IL-7, IL-4, PDGF- $\beta \beta$, IL-6, IL-1 $\beta$, MIP- $1 \alpha$, MIP- $1 \beta$ and TNF- $\alpha$. Raised concentrations of IL- 4 , MIP- $1 \alpha$, TNF- $\alpha$, IL-1 $\beta$, IL- 6 , IL-7 and G-CSF have each been associated with the control of HSV-1 infection in murine models, ${ }^{31-39}$ suggesting that the reduction in these cytokine concentrations may reflect the detection of HSV-1 DNA in the context of a loss of viral immune control. The presence of HSV-1 DNA was also associated with significant decreases in genital concentrations of five of nine proinflammatory cytokines integral to defining the relationship between inflammation and HIV risk (IL-6, IL-1 $\beta$, MIP- $1 \alpha$, MIP-1 $\beta$ and TNF- $\alpha)^{4}{ }^{4}$ However, while inflammation and elevated chemotactic cytokine concentrations increase HIV risk, ${ }^{4} 15$ these associations were all negative and suggest that HSV-1 replication may not contribute to the cytokine environment previously shown to promote HIV risk in this population. However, considering the similarity in viral properties between HSV-1 and HSV-2, this interpretation seems unlikely. This cohort was asymptomatic for HSV infection, that is, with no evidence of the genital lesions associated with inflammation and with increased access of HIV to appropriate genital target cells. It is not clear why the high genital HSV-1 burden did not manifest in symptoms, or whether symptomatic HSV-1 infection contributes to the genital inflammation and the related increase in HIV risk, and larger studies with appropriate consideration of genital HSV symptoms are required to address this. Nonetheless, the data that HSV-1 DNA replication occurs in the context of reduced proinflammatory cytokine levels are substantial and suggest that efforts to limit genital inflammation, perhaps in order to control bacterial infection or to reduce HIV risk, would need to consider implementing additional strategies to restrict replication of local HSV.

This study is limited in its sample size, lack of cellular data to correlate with cytokine profiles and the absence of participants with HSV infections symptoms. Although factors such as age, ${ }^{41}$ oral sex ${ }^{42}$ and number of sexual partners ${ }^{43}$ have been previously associated with HSV-1 DNA detection in women, that this was not observed in this study may be related to sample size and/or the absence of symptomatic herpes infections in the population. Blood specimen sampling was not conducted in the parent study, so HSV serology could not be employed to identify participants exposed to HSV. However, HSV seropositivity (particularly HSV-1) would not provide the useful information about the site of exposure. Another limitation of the study was in the cytokine panel used. Although there was a measure of overlap, the panel was designed to describe genital inflammation in women, 4518 and further studies are needed to assess the role of a broader set of cytokines associated specifically with HSV control. 
Taken together, our study demonstrated that HSV-1 infection is not uncommon in our population and that it is associated with a significantly altered genital cytokine profile. The data demonstrate that HSV-1 replication can occur in the context of lower cytokine concentrations, and suggest that efforts to reduce genital inflammation may therefore need to consider introducing additional precautions to prevent HSV-1 reactivation or seeding.

\section{Key messages}

- The detection of genital HSV-1 DNA is more common among young South African women compared with HSV-2 DNA.

- HSV-1 DNA detection is associated with decreased concentrations of specific genital IL-4, IL-6, IL-7, IL-1 $\beta$, G-CSF, MIP- $1 \alpha$, MIP- $1 \beta$, TNF- $\alpha$ and PDGF- $\beta \beta$ cytokines.

\section{Handling editor Anna Maria Geretti \\ Twitter Nigel Garrett @nigegarrett}

Contributors AnM and LJPL conceptualised and designed the project; FO, LJPL and AnM contributed to data analysis and interpretation; AdM, LJPL, NG and SN reviewed the manuscript; RS and AnM performed the experiments. All authors contributed to the preparation of the manuscript.

Funding The CAPRISA 083 study was funded by a United States-South African Program for Collaborative Biomedical Research grant through the South African Medical Research Council and the National Institute of Health (Al116759). This research was conducted as part of the DSI-NRF Centre of Excellence in HIV Prevention, which is supported by the Department of Science and Innovation, and the National Research Foundation. AnM received support from the CAPRISA Research Administration and Management Training Program (grant no. G11 TW010555-01). LJPL is funded by a SANTHE Path to Independence award, and by a FLAIR Fellowship supported by the African Academy of Sciences and the Royal Society.

\section{Competing interests None declared.}

\section{Patient consent for publication Not required.}

Ethics approval This study was approved by the Biomedical Research Ethics Committee of the University of KwaZulu-Natal (Ref: BE403/16).

Provenance and peer review Not commissioned; externally peer reviewed.

Data availability statement Data are available upon request (https://www. caprisa.org/Pages/CAPRISAStudies).

Open access This is an open access article distributed in accordance with the Creative Commons Attribution Non Commercial (CC BY-NC 4.0) license, which permits others to distribute, remix, adapt, build upon this work non-commercially, and license their derivative works on different terms, provided the original work is properly cited, appropriate credit is given, any changes made indicated, and the use is non-commercial. See: http://creativecommons.org/licenses/by-nc/4.0/.

\section{ORCID iDs}

Ravesh Singh http://orcid.org/0000-0002-0407-4635

Lenine J P Liebenberg http://orcid.org/0000-0001-6768-8776

\section{REFERENCES}

1 Looker KJ, Johnston C, Welton NJ, et al. The global and regional burden of genita ulcer disease due to herpes simplex virus: a natural history modelling study. BMJ Glob Health 2020:5:e001875.

2 Durukan D, Fairley CK, Bradshaw CS, et al. Increasing proportion of herpes simplex virus type 1 among women and men diagnosed with first-episode anogenital herpes: a retrospective observational study over 14 years in Melbourne, Australia. Sex Transm Infect 2019;95:307-13.

3 Chaabane S, Harfouche M, Chemaitelly $\mathrm{H}$, et al. Herpes simplex virus type 1 epidemiology in the Middle East and North Africa: systematic review, meta-analyses, and meta-regressions. Sci Rep 2019;9:1-11.

4 Masson L, Passmore J-AS, Liebenberg LJ, et al. Genital inflammation and the risk of HIV acquisition in women. Clin Infect Dis 2015;61:260-9.

5 McKinnon LR, Liebenberg LJ, Yende-Zuma N, et al. Genital inflammation undermines the effectiveness of tenofovir gel in preventing HIV acquisition in women. Nat Med $2018 ; 24: 491$
6 Johnston C, Corey L. Current concepts for genital herpes simplex virus infection: diagnostics and pathogenesis of genital tract shedding. Clin Microbiol Rev 2016;29:149-61.

7 Martinelli E, Tharinger H, Frank I, et al. HSV-2 infection of dendritic cells amplifies a highly susceptible HIV-1 cell target. PLoS Pathog 2011;7:1-14.

8 Posavad CM, Zhao L, Mueller DE, et al. Persistence of mucosal T-cell responses to herpes simplex virus type 2 in the female genital tract. Mucosal Immunol 2015;8:115-26.

9 Sivro A, Schuetz A, Sheward D, et al. Integrin $\alpha 4 \beta 7$ expression on peripheral blood CD4+ T cells predicts HIV acquisition and disease progression outcomes. Sci Trans/ 2018;10:1-23.

10 Burrel S, Boutolleau D, Ryu D, et al. Ancient recombination events between human herpes simplex viruses. Mol Biol Evol 2017;34:1713-21

11 Melchjorsen J, Sirén J, Julkunen I, et al. Induction of cytokine expression by herpes simplex virus in human monocyte-derived macrophages and dendritic cells is dependent on virus replication and is counteracted by ICP27 targeting NF-kappaB and IRF-3. J Gen Virol 2006:87:1099-108.

12 Zhu J, Koelle DM, Cao J, et al. Virus-specific CD8+ T cells accumulate near sensory nerve endings in genital skin during subclinical HSV-2 reactivation. J Exp Med 2007;204:595-603.

13 Johnson KE, Chikoti L, Chandran B. Herpes simplex virus 1 infection induces activation and subsequent inhibition of the IFI16 and NLRP3 inflammasomes. J Virol 2013;87:5005-18.

14 Chew T, Taylor KE, Mossman KL. Innate and adaptive immune responses to herpes simplex virus. Viruses 2009;1:979-1002

15 Arnold KB, Burgener A, Birse K, et al. Increased levels of inflammatory cytokines in the female reproductive tract are associated with altered expression of proteases, mucosal barrier proteins, and an influx of HIV-susceptible target cells. Mucosal Immunol 2016;9:194-205

16 Garrett NJ, Osman F, Maharaj B, et al. Beyond syndromic management: opportunities for diagnosis-based treatment of sexually transmitted infections in low- and middleincome countries. PLoS One 2018;13:e0196209.

17 Garrett N, Mitchev N, Osman F, et al. Diagnostic accuracy of the Xpert CT/NG and OSOM Trichomonas rapid assays for point-of-care STI testing among young women in South Africa: a cross-sectional study. BMJ open 2019:9:1-5.

18 Archary D, Liebenberg LJ, Werner L, et al. Randomized cross-sectional study to compare HIV-1 specific antibody and cytokine concentrations in female genital secretions obtained by menstrual cup and cervicovaginal lavage. PLoS One 2015:10:1-16

19 Namvar L, Olofsson S, Bergström T, et al. Detection and typing of herpes simplex virus (HSV) in mucocutaneous samples by TaqMan PCR targeting a gB segment homologous for HSV types 1 and 2. J Clin Microbiol 2005;43:2058-64.

20 Ramchandani MS, Jing L, Russell RM, et al. Viral genetics modulate orolabial herpes simplex virus type 1 shedding in humans. J Infect Dis 2019:219:1058-66.

21 Schiffer JT, Mayer BT, Fong Y, et al. Herpes simplex virus-2 transmission probability estimates based on quantity of viral shedding. J $R$ Soc Interface 2014;11:20140160.

22 Legoff J, Bouhlal H, Grésenguet G, et al. Real-time PCR quantification of genital shedding of herpes simplex virus (HSV) and human immunodeficiency virus (HIV) in women coinfected with HSV and HIV. J Clin Microbiol 2006;44:423-32.

23 Tobian AAR, Grabowski MK, Serwadda D, et al. Reactivation of herpes simplex virus type 2 after initiation of antiretroviral therapy. J Infect Dis 2013;208:839-46.

24 Smith JS, Robinson NJ. Age-specific prevalence of infection with herpes simplex virus types 2 and 1: a global review. J Infect Dis 2002;186:S3-28.

25 Vyse AJ, Gay NJ, Slomka MJ, et al. The burden of infection with HSV-1 and HSV-2 in England and Wales: implications for the changing epidemiology of genital herpes. Sex Transm Infect 2000;76:183-7.

26 Roberts CM, Pfister JR, Spear SJ. Increasing proportion of herpes simplex virus type 1 as a cause of genital herpes infection in college students. Sex Transm Dis 2003:30:797-800

27 Ribes JA, Steele AD, Seabolt JP, et al. Six-year study of the incidence of herpes in genital and nongenital cultures in a central Kentucky medical center patient population. J Clin Microbiol 2001;39:3321-5.

28 Wald A. Genital HSV-1 infections. In: The Medical Society for the Study of Venereal Disease. , 2006: 82, 189-90.

29 Schillinger JA, Xu F, Sternberg MR, et al. National seroprevalence and trends in herpes simplex virus type 1 in the United States, 1976-1994. Sex Transm Dis 2004;31:753-60.

30 Halpern-Felsher BL, Cornell JL, Kropp RY, et al. Oral versus vaginal sex among adolescents: perceptions, attitudes, and behavior. Pediatrics 2005;115:845-51.

31 Wiryana P, Bui T, Faltynek CR, et al. Augmentation of cell-mediated immunotherapy against herpes simplex virus by interleukins: comparison of in vivo effects of IL-2 and IL-7 on adoptively transferred T cells. Vaccine 1997;15:561-3.

32 Minami M, Kita M, Yan X-Q, et al. Role of IFN-gamma and tumor necrosis factor-alpha in herpes simplex virus type 1 infection. $J$ Interferon Cytokine Res 2002:22:671-6.

33 Lucinda N, Figueiredo MM, Pessoa NL, et al. Dendritic cells, macrophages, NK and CD8+ T lymphocytes play pivotal roles in controlling HSV-1 in the trigeminal ganglia by producing IL1-beta, iNOS and granzyme B. Virol J 2017;14:1-15. 
34 LeBlanc RA, Pesnicak L, Cabral ES, et al. Lack of interleukin-6 (IL-6) enhances susceptibility to infection but does not alter latency or reactivation of herpes simplex virus type 1 in IL-6 knockout mice. J Virol 1999;73:8145-51.

35 Mikloska Z, Danis VA, Adams S, et al. In vivo production of cytokines and beta (C-C) chemokines in human recurrent herpes simplex lesions-do herpes simplex virus-infected keratinocytes contribute to their production? I Infect Dis 1998; 177:827-38.

36 Ghiasi H, Osorio Y, Perng GC, et al. Recombinant herpes simplex virus type 1 expressing murine interleukin-4 is less virulent than wild-type virus in mice. J Virol 2001;75:9029-36

37 Brown MA, Hural J. Functions of IL-4 and control of its expression. Crit Rev Immunol 1997:17:1-32.

38 Ellermann-Eriksen S. Macrophages and cytokines in the early defence against herpes simplex virus. Virol J 2005;2:59.
39 Tumpey TM, Chen SH, Oakes JE, et al. Neutrophil-mediated suppression of virus replication after herpes simplex virus type 1 infection of the murine cornea. J Virol 1996;70:898-904.

40 Gosmann C, Anahtar MN, Handley SA, et al. Lactobacillus-deficient cervicovaginal bacterial communities are associated with increased HIV acquisition in young South African women. Immunity 2017;46:29-37.

41 Harfouche M, Chemaitelly H, Abu-Raddad LJ. Herpes simplex virus type 1 epidemiology in Africa: systematic review, meta-analyses, and meta-regressions. $J$ Infect 2019;79:289-99.

42 Nieuwenhuis RF, van Doornum GJJ, Mulder PGH, et al. Importance of herpes simplex virus type-1 (HSV-1) in primary genital herpes. Acta Derm Venereol 2006;86:129-34.

43 Tideman RL, Taylor J, Marks C, et al. Sexual and demographic risk factors for herpes simplex type 1 and 2 in women attending an antenatal clinic. Sex Transm Infect 2001;77:413-5. 